\title{
TEACHERS' UNDERSTANDING OF EVIDENCE OF STUDENTS' SOCIAL EMOTIONAL LEARNING AND SELF-REPORTED GAINS OF MONITORED IMPLEMENTATION OF SEL TOOLKIT
}

\author{
BAIBA MARTINSONE \\ Department of Psychology, Faculty of Education, Psychology and Art, \\ University of Latvia \\ Imantas 7. līnija -1, Riga, LV1083, Latvia \\ E-mail address: baiba.martinsone@lu.lv \\ ORCID ID: https://orcid.org/0000-0001-9404-1759 \\ MARCO FERREIRA \\ Instituto Superior de Educação e Ciências, ISEC School of Education \\ Alameda das Linhas de Torres, 179, 1750-142, Lisboa, Portugal \\ E-mail address: marco.ferreira@iseclisboa.pt \\ ORCID ID: https://orcid.org/0000-0002-5547-4188

\section{SANELA TALIĆ} \\ Institute for research and development UTRIP \\ Trubarjeva cesta 13, 1290, Grosuplje, Slovenia \\ E-mail address: sanela.talic@gmail.com \\ ORCID ID: https://orcid.org/0000-0002-3602-4915
}

\begin{abstract}
Aim. The aim of this study was to highlight and analyse teachers' responses to the evidence of their students' social emotional growth and teachers' own gains from the monitored implementation of social emotional learning in their classes.

Methods. The research group was composed of 312 teachers from Latvia and Slovenia, who were involved in the implementation of indirect social emotional learning through classroom instruction and formative assessment. A thematic analysis of the teachers' written responses was performed.

Results. A thematic analysis of the teachers' responses indicated that initially they had mentioned mostly (expressed) general statements and only some small part of their responses included observable and measurable indicators of students' social emotional skills improvement. Therefore, four months after the beginning of the intervention, teachers reported rather on their personal and professional gains from the participation in this intervention than provided general statements.
\end{abstract}


Conclusions. The teachers' improved self-reflection is a premise for them to consider evidence of students' social emotional skills development thus facilitating purposeful social emotional learning in schools.

Key words: social emotional learning, teacher self-reflections, evidence of social emotional development

\section{INTRODUCTION}

Tn a complex and progressively more demanding society, students must be prepared not only to succeed in school but also to be successful in life. In this way, social emotional learning is of great importance in the educational context, because an effective education is not just about the content but also about the social and emotional conditions under which students are learning. Social emotional learning (SEL) is the process of developing the ability to recognise and manage emotions, care and concern for others, make responsible decisions, establish positive relationships, and handle challenging situations effectively (CASEL, 2005). Social emotional competence includes students' ability to communicate effectively with others, cooperate and actively engage in different tasks with peers, solve problems, resist social pressure and seek help when necessary. Social emotional competence supports students' strengths and prevents them from such problems as violence, drug abuse, or absenteeism and dropping out of school. The close relationship among social emotional skills, academic achievement, lifelong learning and general psychological well-being have been highlighted in various sources (Durlak, Weissberg, Dymnicki et al., 2011; Zins, Weissberg, Wang, \& Walberg, 2004). In fact, such learning helps students confront various adversities, while providing them with more responsibility, autonomy, self-awareness, self-confidence and motivation. Evidence of a key role of social emotional competence with regard to the students' overall development has been increasingly recognised, particularly in the school context (Elias et al., 1997). In schools, SEL can be provided directly through special learning programmes and also indirectly - through effective instruction, formative assessment, encouraging students' engagement in constructive activities in and out of the classroom. Teacher involvement plays a crucial role in planning, implementation, and evaluation of effectiveness of SEL (Zins, Weissberg, Wang, \& Walberg, 2004), because teachers are the locomotive that drives social and emotional learning in schools and classrooms. Classrooms with deep teacher-student relations support positive social emotional competence development among students (Schonert-Reichl, 2017). Extensive research evidence confirms that SEL skills can be taught and measured (Durlak, Weissberg, Dymnicki, Taylor, \& Schellinger, 2011). To be effective and active, SEL development practices and interventions should occur in a safe, caring, and participatory environment, that is, in an environment that supports and organises students' actions and lets them practice spontaneously the skills they learn. Schonert-Reichl (2017) suggests that those children who feel comfortable with their teachers and peers are more willing to cope with challenging mate- 
rial and maintain perseverance at difficult learning tasks. Research informs us that a warm classroom environment and positive teacher-student relationships promote both academic and social emotional learning (Payton et al., 2008).

Several factors may affect teachers' ability to deliver SEL activities inside their classrooms. One of them is time management when teachers may feel that they are not able to reach social emotional needs of their students effectively due to time constraints. Kress, Norris, Schoenholz, Elias, and Siegle (2004) reported teachers' feelings that the emphasis on academic contents and standards outweighed any focus placed on social emotional skills. The emphasis mainly on the academic curriculum could impact negatively the development of activities that could lead to a positive social and emotional environment within a classroom. Another factor affecting teachers' ability to implement SEL, is curriculum management when teachers do not know how to incorporate social emotional skill development into their curriculum (Hoffman, 2009) In addition, they do not feel confident in their knowledge of how to address social emotional skills in their classrooms (Pavri \& Hegwer-DiVita, 2006). Previous research has demonstrated that teachers feel they need to be provided with more professional development opportunities like in-service training or workshops, to acquire the necessary skills for implementing of SEL practices and meeting the social emotional needs of their students (Battalio \& Stephens, 2005). One more factor that could affect teachers' capability to implement SEL is associated with necessity to change teachers' own attitudes and practices (Jones \& Bouffard, 2012) both at personal and professional levels. This includes a wide range of activities such as setting clear goals, strengthening open communication, being sensitive and respectful of differences among individuals, teaching through modelling, developing strategies for dealing with emotions and resolving conflicts, fostering positive development of all students, as well as monitoring the change process (CASEL, 2005; McNeeley, Nonnemaker, \& Blum, 2002).

Finally, teachers could resist SEL because of insufficient knowledge how to assess an improvement of their students' social emotional skills. Regular assessment of SEL provides a teacher with information about students' social emotional development as well as allowing improving SEL-related instruction and programming. In other words, we can use assessment of social and emotional knowledge, skills and abilities to understand the development of individual students. In addition, we can aggregate the resulting data in the classroom and school for continuous improvement and evaluation of SEL (Klinger et al., 2015). Like other formative assessments in educational settings, SEL assessments are intended to inform decision-making at classroom and school, and should be used for continuous improvement (Yoder, 2014) and sustaining progress (Millett, Payne, Dwyer, Stickler, \& Alexiou, 2008). Formative assessment has the aim to improve teacher practice and ultimately enhance student learning. Systematic assessment procedures can identify students who do not make as much progress as expected. In this way, formative assessment can be considered as a key component of well-regulated learning environments. 
From this perspective, the task of a teacher is to plan and create situations in which students learn effectively (Black \& Wiliam, 2004), for example, through combining formative assessment practices with addressing students' social emotional competences in the classroom. McKown (2017) refers that SEL assessments should follow several principles, meeting the highest ethical standards, being targeted at specific skills and developmentally appropriate. They should be developed specifically for educational settings, evaluating dimensions of SEL that span the categories of thinking, behavioural, and self-control skills. Teachers should become familiar with, adopt, and use existing, well-designed SEL assessments for appropriate purposes, formative assessment, progress monitoring, and program evaluation (McKown, 2017).

Taking into account the fact that teachers should develop the skills of self-reflection and monitor their students' social emotional development, this research is targeted at answering two questions. First, what evidence is expected regarding students' social emotional development before the implementation of SEL intervention and, second, what are the teachers' self-reported gains from implementing the SEL intervention in their classrooms? The link between the first and the second question of this research is based on the assumption that by developing teachers' understanding regarding social emotional learning in school, teachers would start to look for evidence of improvement in students' social emotional skills more intentionally. Thus, teachers would be able to provide more space for practicing social emotional skills in different settings. As a result, it could be expected that they have adopted a skill to intentionally search for evidence (in form of measurable behavioural indicators) with respect to students' social emotional growth.

\section{METHOD}

\section{Research participants}

The research participants were 312 teachers from twenty experimental schools in Latvia and Slovenia. These teachers participated in an international project during which they learned approaches and strategies for the development of students' social emotional skills through classroom instruction and formative assessment in every subject's lessons. The target groups of the whole intervention were students from grades 3 to 4 and 7 to 8 . Their teachers were involved in this project as well. There were even more teachers who wanted to participate in the project. Because of this, we also included in the research some other teachers from experimental schools, who initially attended the teacher training seminar and who fulfilled the training evaluation form as well as implemented the intervention in their classes. There were 187 teachers (169 female and 18 male) from 10 schools in Latvia and 125 teachers (121 female and 4 male) from ten schools in Slovenia. The participants' teaching experience ranged from one year to more than forty years. From those teachers 75 from Slovenia and 55 from Latvia participated in the project's national conference 
in their countries during which they provided written answers that revealed what they had gained from the participation in the project. These answers were analysed in accordance with the second research question.

Context of the research and monitoring procedure of the intervention

The current research is a part of the international project "Learning to be: Development of practices and methodologies for assessing social, emotional and health skills within education systems". Seven European countries - Lithuania, Latvia, Italy, Slovenia, Spain, Finland and Portugal joined the research project with quasi experimental design in order to develop the intervention and evaluate the effectiveness of implementation of SEL Toolkit (Agliati et al., 2018 ) in schools in five partner countries (Lithuania, Latvia, Italy, Slovenia and Spain). In these countries, research groups were formed by selecting twenty participant schools, from which 10 were experimental and 10 - control schools. In all participant schools, the effectiveness of the intervention was measured through comparing results of pre- and post-tests, evaluating the effect on social emotional competence, health behaviour and other variables of the teachers and students of two age groups ( $3^{\text {rd }}-4^{\text {th }}$ grades and $7^{\text {th }}-8^{\text {th }}$ grades). For intervention, a set of practical methods' named Toolkit was developed for the implementation of SEL in everyday teaching routine through a real content of subject programmes. The novelty of this approach was to combine in one ready-to-use teacher's handbook the Illinois state social emotional learning standard, instructive teaching strategies and strategies of formative assessment developed by Dylan Wiliams. The goal of the intervention was to develop a common whole-school approach, based on understanding of how social emotional skills can be developed, supported and assessed consistently in everyday routines. The whole research design consisted of pre-test in all participant schools at the beginning of a school year, followed by teacher and administration training in experimental schools. Then a 5-6-month intervention period followed. Afterwards, a post-test was carried out in all participant schools. Finally, a training for teachers and administrators of control schools was organised. During 2018/2019 school year, simultaneously with starting the intervention, unified monitoring procedures started in all experimental schools. The monitoring was aimed to ensure fidelity of the implementation across five trial countries and also to raise researchers' awareness of possible mixed variables that could interfere with results of the intervention.

During the monitoring, three supervisions for teachers and administration in every experimental school were organised. In these supervisions, school consultants provided professional and emotional support for the participants, answered all their questions with regard to intervention methodology, as well as collecting rich qualitative data on different aspects of the intervention, based on verbal answers and written pieces of self-reflection of participants. In this research, the data stemming from the two sources of monitored intervention were used. The first source was gained from the answers provided by the teachers from experimental school directly after the initial teacher training and second source was obtained after about 4-month active usage of the Toolkit in their work. 


\section{Data collection}

The initial 2-day training for teachers was held at each experimental school and led by the respective school's coordinator. During the seminar, participants were acquainted with the concept of SEL, its theoretical background, approaches to SEL implementation in schools, as well as with the content and usage of the methodological handbook Toolkit. The Toolkit contained detailed descriptions of instructional teaching strategies (e.g. group work, think-pairshare, wait time, setting learning goals, reflection, etc.) and of practical tools for SEL assessment in individual, group and whole-school levels. During the training, the participants had the opportunity to broaden their existing experience on SEL, integrate new knowledge regarding SEL into a classroom, as well as participate in practical exercises regarding the usage of the Toolkit. At the end of the second day of the training, teachers were asked to evaluate the training itself and their own understanding of SEL in writing. One of the questions in the questionnaire was as follows: Which signs will make your students' SEL development visible? Based on the written answers that we received from teachers on this question we defined the first question of this particular research - what evidence of students' social emotional development was expected by teachers before the implementation of SEL intervention?

The second question of this research was developed based on the written answers regarding the benefits of the teachers possibly gained after a 4 month of implementation of the Toolkit. This certainly posed a question: what did the teachers gain from the implementation of the SEL intervention in their classes? These answers were collected during the national conferences in Latvia and Slovenia. These national conferences were organised during the second half of the intervention so that the teachers from the experimental schools could share their experiences of the implementation of the Toolkit. In addition, they shared examples of successful practice and their approaches to overcoming difficulties. All in all, these activities were carried out in order to strengthen the possible collaboration between schools that practice SEL.

\section{Data analysis}

Written answers provided by teachers after initial training, were analysed in accordance with the principles of thematic analysis. Researchers in Latvia and Slovenia independently read and reviewed all the answers in both national languages and noted the units of meaning. Afterwards, in order to perform a combined analysis of full data, all units of the content were directly translated into English. In the next step of the qualitative analysis, all these content units were repeatedly reviewed and grouped into themes, therefore achieving mutual agreement if needed. Finally, the themes were combined into categories. Alongside with the qualitative analysis, the number of relevant answers in each category was counted. Further, a relative frequency of the provided answers was calculated and expressed as a percentage. Due to the fact that one teacher's answers could have contained multiple different content units, a total sum of the amount of relative frequency in all categories exceeded $100 \%$. 


\section{RESULTS}

Answering the first question of the research - what evidence of students' social emotional development was expected by teachers before implementation of SEL intervention, a thematic analysis of the written answers provided by the teachers was carried out. Three thematic categories were established during this analysis.

The first and largest thematic category was Skills from the domains of SEL, which combined the biggest part of the answers - 78\% $(n=243)$. As evidence of student social emotional skill development teachers named skills of SEL construct, which they have had just adopted from teachers' training. The answers contained all groups of SEL competencies - self-awareness, self-management, social-awareness, relationship skills and making responsible decisions. The teachers involved in the project predicted that as a result of the intervention, changes in students' self-awareness ("Understanding themselves"), self-management ("Will be able to control their emotions and behaviour"), social-awareness ("There will be more tolerance"), relationship skills ("Collaboration skills") and making responsible decisions ("Problem solving will improve") would be observed. These answers were declaratory and reflected that the teachers could indicate different aspects of the SEL conceptual model as well as the indicators of evidence-based SEL programmes that were named in the training.

The second largest category representing $35 \%(n=110)$ of the teachers' responses was General statements without measurable indicators. The themes for improvements such as class and school climate ("Positive emotional school climate"), the improvement of working atmosphere in lessons ("Students will learn creatively", "More positive attitude toward the work during a lesson"). Also, emotional well-being ("Satisfaction", "More autonomy") was named in answers provided by the teachers.

The smallest category included Observable and measurable indicators that were named only in $12 \%(n=37)$ of the answers provided by the teachers as evidence for the students' social emotional development. A relatively small number of the teachers indicated that evidence for their students' social emotional development could be the improvement in their academic performance ("Higher grades", "Better work in terms of accuracy, less mistakes"), improvement in self-reflection ("Will name at least two their emotions", "Ability to provide a feedback in different ways - to reflect on what others have said, to fill in self-assessment cards regularly"). The signs of active participation were highlighted as one of the themes in the teachers' answers. Respondents predicted that clear evidence regarding students' social emotional development will be data-based improvement in school attendance, increased learning motivation ("Will decrease school nonattendance", "More active in asking questions", "Will be able to say, what exactly they will expect to learn") of their students. 
Table 1

Categories, themes with example quotations and frequency distribution of teachers' answers to the question: Which signs will make your students' SEL development visible? before the implementation of the SEL Toolkit

\begin{tabular}{|c|c|c|c|}
\hline Category & Themes & Example quotations & $\begin{array}{l}\text { Frequencies } \\
(\mathrm{n}=312)\end{array}$ \\
\hline $\begin{array}{l}\text { Skills from } \\
\text { the } \\
\text { domains of } \\
\text { SEL }\end{array}$ & $\begin{array}{l}\text { Self-awareness } \\
\text { Self-management } \\
\text { Social-awareness } \\
\text { Relationship skills } \\
\text { Responsible decisions }\end{array}$ & $\begin{array}{l}\text { "Understanding of themselves" } \\
\text { "Will be able to control their } \\
\text { emotions and behaviour" } \\
\text { "Better relationship" } \\
\text { "The decision-making skills will } \\
\text { improve" }\end{array}$ & $\begin{array}{l}78 \% \\
(n=243)\end{array}$ \\
\hline
\end{tabular}

\begin{tabular}{|c|c|c|c|}
\hline $\begin{array}{l}\text { General } \\
\text { statements } \\
\text { without } \\
\text { measurable } \\
\text { indicators }\end{array}$ & $\begin{array}{l}\text { Class and school } \\
\text { climate } \\
\text { Improvement of } \\
\text { working atmosphere } \\
\text { in lessons } \\
\text { Emotional well-being }\end{array}$ & $\begin{array}{l}\text { "Feeling better at school" } \\
\text { "Responsible work during lessons" } \\
\text { "More interest in personal growth" } \\
\text { "Better health" } \\
\text { "More autonomy" } \\
\text { "Understanding of their own place } \\
\text { in the system of education" }\end{array}$ & $\begin{array}{l}35 \% \\
(n=110)\end{array}$ \\
\hline $\begin{array}{l}\text { Observable } \\
\text { and } \\
\text { measurable } \\
\text { indicators }\end{array}$ & $\begin{array}{l}\text { Improvement in } \\
\text { academic performance } \\
\text { Evidence of } \\
\text { improvement in self- } \\
\text { reflection (ability to } \\
\text { reflect verbally and in } \\
\text { a written form) } \\
\text { Signs of active } \\
\text { participation }\end{array}$ & $\begin{array}{l}\text { "Higher grades" } \\
\text { "Will demonstrate initiative by } \\
\text { asking relevant questions" } \\
\text { "After a lesson will be able to } \\
\text { say what have learned, what still } \\
\text { remains unclear" } \\
\text { "After problematic situations, } \\
\text { students will be able to analyse } \\
\text { behaviour of their own and others; } \\
\text { will be able to define causes and } \\
\text { consequences of a situation" } \\
\text { "Improvement of quality of notes } \\
\text { in self-assessment cards" } \\
\text { "Students who were previously } \\
\text { afraid to express their views, are } \\
\text { doing so now" } \\
\text { "Will decrease school } \\
\text { nonattendance" }\end{array}$ & $\begin{array}{l}12 \% \\
(n=37)\end{array}$ \\
\hline
\end{tabular}

Source: own research

In order to answer the second question of the research - what were the teachers' own benefits after 4-month of implementation of the Toolkit, the written answers of the respondents provided during the national conferences were analysed. The three main categories of the teachers' responses were established during a thematic analysis. 
Table 2

Categories, themes with example quotations and frequency distribution of teachers' answers to the question: What have you gained after 4-month of active implementation of the SEL Toolkit

\begin{tabular}{|c|c|c|c|}
\hline Category & Themes & Example quotations & $\begin{array}{l}\text { Frequencies } \\
(\mathrm{n}=312)\end{array}$ \\
\hline $\begin{array}{l}\text { Personal } \\
\text { growth }\end{array}$ & $\begin{array}{l}\text { Emotional } \\
\text { expression } \\
\text { Self-confidence } \\
\text { Self- } \\
\text { management } \\
\text { Personal- } \\
\text { behavioural } \\
\text { Personal- } \\
\text { communicative }\end{array}$ & $\begin{array}{l}\text { "I am empathetic and more and } \\
\text { more patient" } \\
\text { "I know how to stop and breathe" } \\
\text { "I started to communicate with my } \\
\text { students more emotionally, so } \\
\text { our relationship became more } \\
\text { in-depth" } \\
\text { "I have become more socially } \\
\text { responsible and help also to } \\
\text { strangers" } \\
\text { "Project inspired me to change } \\
\text { my point of view on parents as } \\
\text { partners" }\end{array}$ & $\begin{array}{l}54 \% \\
(n=70)\end{array}$ \\
\hline Professional & $\begin{array}{l}\text { Devoting time } \\
\text { to SEL } \\
\text { Professional } \\
\text { collaboration } \\
\text { Using new } \\
\text { methods }\end{array}$ & $\begin{array}{l}\text { "I started to focus more on HOW } \\
\text { to teach not WHAT to teach" } \\
\text { "To set SEL as priority" } \\
\text { "Now, I cooperate well with } \\
\text { colleagues" } \\
\text { "I implemented in my daily } \\
\text { routine such methods as Wait } \\
\text { time and Traffic lights" } \\
\text { "Now, I provide feedback more } \\
\text { intentionally" }\end{array}$ & $\begin{array}{l}30 \% \\
(n=39)\end{array}$ \\
\hline $\begin{array}{l}\text { General } \\
\text { statements }\end{array}$ & & $\begin{array}{l}\text { "With simple approach, we are } \\
\text { able to make big changes" } \\
\text { "There is still room for } \\
\text { improvement" } \\
\text { "I am on a "right track"" } \\
\text { "It is better not to stick with things } \\
\text { that cannot be resolved" }\end{array}$ & $\begin{array}{l}16 \% \\
(n=21)\end{array}$ \\
\hline
\end{tabular}

Source: own research

The thematic category Personal growth was represented by $54 \%(n=70)$ of the teachers' answers. The respondents acknowledged that through intensive self-reflection they had become more aware of emotional self-expression ("I have to work more on my feelings", "I started to communicate kindly"). They also expressed more self-confidence at a personal level ("I trust myself more and believe that changes are possible"), reported the improved ability to manage their own emotions ("I calm down a little bit in the classroom", "I can be patient with others"), as well as observed changes in communicative and behavioural aspects ("Now, I am more able to listen 
to others", "I apply the project's methods with my own children - now, there are less conflicts").

The second largest category with $30 \%(n=39)$ of the teachers' responses was identified as Professional growth. The teachers reported that during the 4-month participation in the project, they started to devote more time to social emotional learning ("I pay more attention to providing feedback"), improved their collaboration with colleagues ("I know better what my colleagues do we became closer"), and purposefully used methods of the Toolkit ("I devote attention to setting goals, because students learn quick and more if they are part of planning").

The third and the smallest category included General statements without clear reference to concrete benefits or lessons learned although overall mood of answers was positive. Such answers as "Teamwork leads to changes" or "SEL skills are a basis for everything else" were named in $16 \%(n=21)$ of the teachers' reflections.

\section{DISCUSSION}

Thematic analysis of the teachers' written answers was performed to identify their opinions with regard to evidence of their students' social emotional growth and their own gains from the implementation of the SEL Toolkit in their everyday practices of teaching, instructing and assessment.

To answer the first research question as to what evidence of students' social emotional development was expected by the teachers before implementation of SEL intervention, the three thematic categories of the answers were established. Overall, the teachers believed in a positive impact of SEL on their students' social emotional development; therefore, the majority of the answers covered the first two categories that included general statements and skills of the five SEL domains. This revealed the teachers' insufficient awareness of how their students' non-academic improvement could be measured. The teachers believed that during the implementation of the SEL Toolkit, the students' willingness to learn would improve, relationship skills would develop as well as self-awareness and many other skills. However, these answers did not contain any clear indicators of how teachers could observe and assess these improvements. If teachers are not ready to assess their students' social emotional development, then teachers will not able to adapt their teaching approaches to their students' needs. Previous research has also shown that teachers can promote their students' social emotional development through creating secure and caring classroom environments and providing them with formative assessment with regard to both outcomes and process of SEL (e.g., Brackett et al., 2012; Christenson \& Havsy, 2004; Millet et al., 2008; Schonert-Reichl et al., 2017; Yoder, 2014). It might be proposed that clearer recognition of evidence of students' social emotional development would promote teachers' intentional effort to implement and assess social emotional learning in their classrooms. 
In relatively few answers the teachers noted observable and measurable indicators as evidence of their students' social emotional growth.

"Students will participate in lessons actively (ask questions, request feedback, collaborate in groups with every classmate); will demonstrate mutual respect in communication (would not talk at the same time, when another speaks, would listen to another person's opinion, and express their own opinion); will be able to formulate the goal of a lesson and reflect on what exactly they have learned."

This quotation reveals the role of teachers' competence to assess their students SEL progress on both individual and whole class level. Intentional and conscious search for indicators of students' social emotional skills' development opens the door to data-based conclusions made by the teacher. These conclusions are important in order to plan further activities, adapt and modify teaching strategies as well as self-reflect on teacher's own social emotional skills and teaching practices.

In answer to the second research question - what were teachers' own benefits after a four month of implementation of the Toolkit in their classrooms, the respondents acknowledged mostly personal and professional gains. It was an opposite tendency in comparison to mostly general answers provided with regard to the first research question. Before the intervention, the teachers mostly answered generally but some months later, their awareness of evidence of changes increased. The importance of teachers' personal and professional role, as well as self-reflection was substantiated in previous research (e.g. Martinsone \& Damberga, 2016). In the current study, the teachers were able to reflect that they notice personal changes but also the tendency to apply already well established and automatic behavioural models.

"I have become more open, confident and emotionally stable. The project has generated positive emotions in me" and "I continue to follow the established (learned) patterns of teaching, but I see that I can change that."

This also corresponds to the findings of other researchers who acknowledged that school-based SEL programmes could positively affect teachers and promote the development of teachers' own social emotional competencies (CASEL, 2005, 2013). The research shows that teachers with better social emotional skills have greater self-efficacy and greater enjoyment of teaching (Goddard et al., 2004). Among the positive gains reported by teachers were improved self-regulation, better communication with students, closer collaboration with colleagues and parents as well as personal openness to applying new teaching strategies, thus incorporating social emotional learning in their everyday teaching routine. The monitored implementation of SEL Toolkit provided teachers with educational, methodological and personal support through the teacher training and regular supervisions. The highlighted role of teachers' personal and professional development in providing a high-quality social emotional learning aligns with conclusions of previous studies. Yoder (2014) suggests that teachers when asked to adopt new practices initially try to understand the meaning of these changes for them, for their 
colleagues, and for their students. This might have an impact on teachers' willingness and motivation to adopt new teaching methodologies within the classroom (Jones \& Bouffard, 2012). Training and continuous professional development creates safe spaces for teachers to try out new practices and reflect on their own practices to determine for themselves what they need to do differently. Bridges (2012) proposes that teachers need to let go of the old ways, step out of their comfort zones, endure uncertainty, and finally succeed with the new initiative. We believe that this assumption promotes teachers' resilience, their social emotional competencies and, finally, a feeling of professional wellbeing.

\section{CONCLUSIONS AND LIMITATIONS}

This research addressed all the previously mentioned factors that could have a negative impact on teachers' ability and motivation to implement SEL in their classrooms. These were - emphasis mainly on achieving of academic goals, insufficient knowledge of how to implement SEL in a daily teaching routine, necessity to improve both personally and professionally as well as challenges that may arise when assessing the students' social emotional improvement. Before the intervention, for teachers from the two countries - Latvia and Slovenia - experienced difficulties with identifying observable and measurable indicators of their students' social emotional growth. During the monitored SEL implementation, the teachers were provided with teacher training, the methodological handbook Toolkit and regular supervisions. It helped the teachers to implement SEL interventions in their everyday teaching practices in every subject. The teachers also recognised their personal and professional gains after they had started the intervention. The teachers were more specific in their answers and avoided general statements contrary to how it had been before the intervention when the teachers reflected on their students' social emotional improvement in a general manner.

This research has also some limitations. First, the analysis of the second question was based on the answers of only part of the respondents from the initial sample. Second, the changes in the teachers' opinions with regard to both research questions were not evaluated prior and also after the implementation of the Toolkit.

Acknowledgements: This article was developed as a part of the EU funded Erasmus+ project "Learning to Be: Development of Practices and Methodologies for Assessing Social, Emotional and Health Skills within Education Systems". 


\section{REFERENCES}

[1] Agliati, A., Aguillar Barriga, P., Cifuentes, P.A., Baena, I.B., Beržanskyte, J., Cavioni, V. ... \& Valverde Jimenez, B. (2018). Toolkit for assessing social and emotional skills at school. ESF. ISBN 978-9955-9776-9-8

[2] Battalio, R., \& Stephens, J. (2005). Social skills training: Teacher practices and perceptions. Beyond Behavior, 14(2), 15-21.

[3] Black, P.J., \& Wiliam, D. (2004). Classroom assessment is not (necessarily) formative assessment (and vice-versa). In M. Wilson (Ed.), Towards coherence between classroom assessment and accountability, 103rd Yearbook of the National Society for the Study of Education (part 2). (pp. 183188). Chicago, IL: University of Chicago Press.

[4] Brackett, M.A., Reyes, M.R., Rivers, S.E., Elbertson, N.A., \& Salovey, P. (2012). Assessing teachers' beliefs about social and emotional learning. Journal of Psychoeducational Assessment, 30, 219-236.

[5] CASEL. (2012). 2013 CASEL Guide: Effective social and emotional learning programs: Preschool and elementary school edition. Chicago, IL: Collaborative for Academic, Social, and Emotional Learning (CASEL).

[6] Christenson, S.L., \& Havsy, L.H. (2004). Family-school-peer relationships: Significance for social, emotional and academic learning. In J.E. Zins, R.P. Weissberg, M.C. Wang, \& H. J. Walberg (Eds.), Building academic success on social and emotional learning: What does the research say? (pp. 59-75). New York, NY, US: Teachers College Press.

[7] Collaborative for Academic, Social and Emotional Learning (CASEL). (2005). Safe and sound: An educational leader's guide to evidence-based social and emotional learning programs - Illinois edition. Retrieved October 15th, 2017, from http://casel.org/wpcontent/uploads/2011/04/ Safe_and_Sound_ILedition.pdf

[8] Durlak, J.A., Weissberg, R.P., Dymnicki, A.B., Taylor, R.D., \& Schellinger, K. (2011). The impact of enhancing students' social and emotional learning: A meta-analysis of school-based universal interventions. Child Development, 82(1), 405-432.

[9] Elias, M. J., Zins, J.E., Weissberg, R.P., Frey, K.S., Greenberg, M.T., Haynes, N.M., Kessler, R., Schwab-Stone, M.E., \& Shriver, T.P. (1997). Promoting social and emotional learning: Guidelines for educators. Alexandria, VA: Association for Supervision and Curriculum Development.

[10] Goddard, R.D., Hoy, W.K., \& Hoy, A.W. (2004). Collective efficacy beliefs: Theoretical developments, empirical evidence, and future directions. Educational Researcher, 33, 3-13. doi:10.3102/0013189X033003003

[11] Hoffman, D. (2009). Reflecting on social emotional learning: A critical perspective on trends in the United States. Review of Educational Research, 79(2), 533-556.

[12] Jones, S., \& Bouffard, S. (2012). Social and emotional learning in schools: From programs to strategies. Social Policy Report, 25(4), 1-22.

[13] Klinger, D.A., McDivitt, P.R., Howard, B.B., Munoz, M.A., Rogers, W.T., \& Wylie, E.C. (2015). The classroom assessment standards for PreK-12 teachers. Joint Committee on Standards for Educational Evaluation. Kindle Direct Press.

[14] Kress, J.S., Norris, J.A., Schoenholz, D.A., Elias, M.J., \& Seigle, P. (2004). Bringing together educational standards and social emotional learning: Making the case for educators. American Journal of Education, 111(1), 68-89.

[15] Martinsone, B., \& Damberga, I. (2016). Qualitative analysis of teachers' written self-reflections after implementation of social emotional learning program in Latvia. International Journal of School and Educational Psychology,5(4), 215-225. http://dx.doi.org/10.1080/21683603.2016.12 25236

[16] McKown, C. (2017). Social-emotional assessment, performance, and standards. Future of Children, 27, 157-178.

[17] McNeeley, C.A., Nonnemaker, J.M., \& Blum, R.W. (2002). Promoting school connectedness: Evidence from the national longitudinal study of adolescent health. Journal of School Health, $72,138-146$.

[18] Millett, C.M., Payne, D.G., Dwyer, C.A., Stickler, L.M., \& Alexiou, J.J. (2008). A culture of evidence: An evidence-centred approach to accountability for student learning outcomes. Princeton, NJ: Educational Testing Service. 
[19] Payton, J., Weissberg, R.P., Durlak, J.A., Dymnicki, A.B., Taylor, R.D., Schellinger, K.B., \& Pachan, M. (2008). The positive impact of social and emotional learning for kindergarten to eighth-grade students: Findings from three scientific reviews. Chicago, IL: Collaborative for Academic, Social, and Emotional Learning.

[20] Pavri, S., \& Hegwer-DiVita, M. (2006). Meeting the social emotional needs of students with disabilities: The special educator's perspective. Reading \& Writing Quarterly, 22(2), 139-153.

[21] Schonert-Reichl, K.A. (2017). Social and emotional learning and teachers. The future of children, 27(1), 137-155.

[22] Schonert-Reichl, K.A., Kitil, J., \& Hanson-Peterson, J. (2017). To reach the students, teach the teachers: A national scan of teacher preparation and social and emotional learning. University of British Columbia, Vancouver, BC.

[23] Yoder, N. (2014). Teaching the whole child: Instructional practices that support social-emotional learning in three teacher evaluation frameworks. Washington, DC: Center on Great Teachers and Leaders. Retrieved from http://www.gtlcenter.org/sites/default/files/TeachingtheWholeChild.pdf

[24] Zins, J.E., Weissberg, R.P., Wang, M.C., \& Walberg, H.J. (Eds.). (2004). Building academic success on social and emotional learning: What does the research say? New York: Teachers College Press. 